\title{
The pathophysiology of impulse control disorders in Parkinson disease
}

\author{
Sharmili Balarajah ${ }^{\mathrm{a}}$ and Andrea Eugenio Cavanna $\mathrm{a}^{\mathrm{a}, \mathrm{b}, *}$ \\ a Department of Neuropsychiatry, The Michael Trimble Neuropsychiatry Research Group, BSMHFT and University \\ of Birmingham, Birmingham, UK \\ ${ }^{\mathrm{b}}$ Department of Motor Neuroscience and Movement Disorders, Institute of Neurology and University College \\ London, London, $U K$
}

\begin{abstract}
Aims: This review aims to evaluate the most recent evidence on the pathophysiology of impulse control disorders (ICDs) in Parkinson disease (PD)

Methods: Computerised searches of Medline, Embase and PsycInfo, along with manual searches for grey literature, were conducted and resulted in a total of 16 studies suitable for review.

Results: Evidence was divided into four categories: medication used in PD management, imaging studies, genetic analysis and subthalamic deep brain stimulation (STN-DBS). Analysis of the literature reveals that both intrinsic and extrinsic factors may play a role in the pathophysiology of ICDs in PD. Dysfunction of the mesocorticolimbic pathway and polymorphisms of the dopamine D3 and D4 receptors may increase an individual's susceptibility to the development of ICDs.

Discussion: Dopaminergic medication, particularly dopamine agonists (DAs), increases the risk of developing impulsive behaviours in a PD patient. Further evidence, particularly in the form of prospective studies and randomised controlled trials is required to better establish the pathophysiology of ICDs in PD.
\end{abstract}

Keywords: Deep brain stimulation, dopamine agonists, impulse control disorders, levodopa, Parkinson's disease, pathological gambling

\section{Introduction}

Parkinson disease (PD) is a multisystem neurological condition estimated to affect 6-11 per 6,000 of the general UK population [1]. PD is characterised by the depletion of dopaminergic neurons in the substantia nigra, resulting in an imbalance of the basal ganglia circuitry. This depletion of dopaminergic neurons instigates a variety of symptoms, which can be broadly categorised into motor and non-motor. Whilst much research has provided an insight into the pathophysiology of motor symptoms in PD, this is less so the case for non-motor symptoms.

${ }^{*}$ Corresponding author: Dr. Andrea Eugenio Cavanna MD, Department of Neuropsychiatry, The Barberry National Centre for Mental Health, Birmingham B15 2FG, UK. Tel.: +44 121 3012317; Fax: +44 121 3012291; E-mail: a.cavanna@ion.ucl.ac.uk.
Studies have demonstrated a neuropsychiatric element of PD, one of the most common being impulse control disorders (ICDs) [2]. ICDs is an umbrella term covering a spectrum of conditions, which include pathological gambling and compulsive behaviours such as binge eating and hypersexuality [3] and is defined by the Diagnostic and Statistical Manual of Mental Disorders (DSM-IV-TR) as a failure to resist an impulse, drive or temptation to perform an act that is either physically, psychologically, socially, legally or financially harmful to the patient or others [4]. The prevalence of ICDs in PD varies from 1.7-6.1\% for gambling to 0.4$3 \%$ for hypersexuality and their significance is highlighted by the mention of ICDs in the National Institute for Clinical Excellence (NICE) guidelines for PD [1].

Our current understanding of reward and addiction mechanisms predominantly involves dopaminergic mesocorticolimbic pathways, which encompass sever- 
al brain regions including the prefrontal cortex, ventral striatum and amygdala [3]. Considering pathophysiology of PD, there is evidence that the depletion of dopaminergic neurons not only affects the nigrostriatal pathway but the mesocorticolimbic pathway too [5]. Dopaminergic medication may also induce hyperactivity of this pathway given the presence of several subtypes of dopaminergic receptors within it [6].

Although the symptoms of ICDs can be extremely disabling [7,8], the evidence base for their treatment is limited $[9,10]$, and therefore there is a need to gain further understanding of the pathophysiology of ICDs in PD. This review will evaluate the most recent evidence on the pathophysiology of ICDs in PD.

\section{Methods}

We conducted a systematic literature review according to the methodology suggested by the Prisma guidelines. Computerised searches were run using PubMed, Medline, PsycInfo, Embase, the Cochrane library and Google Scholar. The following search strategy was used: (addict OR gambl* OR impulse OR reward OR dopamine dysregulation syndrome OR compuls* OR hypersexual*) AND Parkinson*. In addition to references obtained by searching the databases mentioned above, the reference lists of pertinent articles were scanned as were the contents pages of significant journals that may have a greater focus on neuropsychiatry and PD (Brain, Journal of Neuropsychiatry and Clinical Neurosciences, The Lancet Neurology, Movement Disorders, Nature Neuroscience, Parkinsonism and Related Disorders).

\subsection{Study inclusion criteria}

To obtain an idea of the current understanding of the pathophysiology of ICDs in PD, references were limited to human studies published within the last three years (2008-July 2011). Of these studies, those to be included in this review were required to have a sample size of greater than $n=20$.

\subsection{Study exclusion criteria}

Other types of articles, such as case reports, case series, letters, editorials and reviews, were excluded from this review. Non-English articles were also excluded.

Once duplicates had been removed from the search results, titles and abstracts were initially reviewed to identify potentially eligible studies. Reference titles and abstracts were scanned and excluded if deemed unfitting to the search topic. The full text of studies that had not been excluded at this stage was then assessed to determine eligibility for inclusion in this review.

\section{Results}

\subsection{Overview of search results}

A total of 268 potentially eligible articles were identified through literature searches (264 from electronic searches and 4 from review of the grey literature). Of these articles 16 were suitable for inclusion in this review.

\subsection{Influence of PD medication in development of ICDs (Table 1)}

Five recent studies have confirmed that the use of medications in the management of PD can lead to the development of ICDs in patients. Pramipexole, one of the most commonly used dopamine agonists (DAs) has been positively associated with patients with $\mathrm{PD}$ who have developed ICDs [24,25] and has been shown to increase the risk of developing PG by 3.65 -fold [25]. Positive correlations found between the total daily levodopa equivalent dose (LED) of DAs and impulsivity [26] provide a strong indication of the involvement of DAs in the development of ICDs in PD. Levodopa, on the other hand, appears to possess a less influential role in the development of ICDs compared to DAs as shown by Weintraub et al. [28]. Evidence suggests, however, that there may be also be an underlying neurobiological vulnerability, which influences ICD development in patients with $\mathrm{PD}$ [27].

\subsection{Imaging studies (Table 2)}

Imaging studies use a range of techniques including functional magnetic resonance imaging (fMRI), positron emission tomography (PET) and voxel-based morphometry (VBM) to investigate the neurobiological correlates of ICDs in PD. Several studies have demonstrated higher rates of activation of the prefrontal cortex, particularly within the orbitofrontal cortex (OFC) [30,31,33]. These studies also implicate the involvement of the striatum in impulsive behaviours: increased striatal activity has been found in both PD patients with ICDs [31,33,34] and PD controls who are 
Table 1

Pharmacotherapy for Parkinson disease and impulse control disorders

\begin{tabular}{|c|c|c|c|c|c|}
\hline Study & Design & Participants & Inclusion criteria & Methodology & Findings \\
\hline $\begin{array}{l}\text { Ondo and } \\
\text { Lai, } \\
2008 \text { [24] }\end{array}$ & $\begin{array}{l}\text { Cross- } \\
\text { sectional }\end{array}$ & $\begin{array}{l}300 \text { patients on DA } \\
\text { medication ( } 207 \text { PD, } \\
89 \text { RLS, } 4 \text { PD \& RLS) }\end{array}$ & Not stated & $\begin{array}{l}\text { Clinical } \\
\text { assessment of } \\
\text { gambling habits, } \\
\text { spending } \\
\text { behaviour, sexual } \\
\text { behaviour/desire } \\
\text { and open } \\
\text { miscellaneous }\end{array}$ & $\begin{array}{l}\text { - Impulsive behaviour more com- } \\
\text { mon in DA agonist-medicated PD } \\
\text { patients vs. RLS patients } \\
\text { - Higher dose of DA agonist found } \\
\text { to be a significant risk factor for } \\
\text { the development of reward seek- } \\
\text { ing behaviour }\end{array}$ \\
\hline $\begin{array}{l}\text { Imamura } \\
\text { et al., } \\
2008 \text { [25] }\end{array}$ & Case-control & $\begin{array}{l}48 \\
\text { (11 PD patients with } \\
\text { newly developed PG } \\
\& 37 \text { age, sex- } \\
\text { matched PD controls) }\end{array}$ & $\begin{array}{l}\text { Diagnosis of PD by } \\
\text { neurologist }\end{array}$ & & $\begin{array}{l}\text { - Greater use of pramipexole in } \\
\text { cases (PD patients with PG) than } \\
\text { controls (PD patients without PG } \\
\text { - Insignificant difference in LED } \\
\text { between cases and controls but } \\
\text { significant but significant dif- } \\
\text { ference in dose of pramipexole } \\
\text { (3.65-fold risk of patients devel- } \\
\text { oping PG if on pramipexole) }\end{array}$ \\
\hline $\begin{array}{l}\text { Torta et } \\
\text { al., } 2009 \text { [26] }\end{array}$ & Case-control & $\begin{array}{l}28 \\
(15 \text { PD patients on and } \\
\text { off medication \& } 13 \\
\text { healthy controls) }\end{array}$ & $\begin{array}{l}\text { Evaluation by two } \\
\text { neurologists }\end{array}$ & CGT & $\begin{array}{l}\text { - Significantly greater impulsivity } \\
\text { in PD patients (on and off medi- } \\
\text { cation) vs. controls } \\
\text { - Positive correlation between de- } \\
\text { gree of impulsivity and LED }\end{array}$ \\
\hline $\begin{array}{l}\text { Voon et al., } \\
\text { 2010a [27] }\end{array}$ & Case-control & $\begin{array}{l}42 \\
(14 \text { PD patients with } \\
\text { ICDs, } 14 \text { PD patient } \\
\text { controls, } 16 \\
\text { medication-free } \\
\text { matched controls) }\end{array}$ & $\begin{array}{l}\text { PD - Queen Square } \\
\text { Brain Bank diagnos- } \\
\text { tic criteria } \\
\text { ICDs - DSM-IV- } \\
\text { TR/McElroy's criteria }\end{array}$ & EDT & $\begin{array}{l}\text { - DA associated with increasing } \\
\text { impulsivity in PD patients with } \\
\text { ICDs but not controls } \\
\text { - PD patients with ICDs on DA } \\
\text { tend to overestimate a risky } \\
\text { choice compared to off }\end{array}$ \\
\hline $\begin{array}{l}\text { Weintraub } \\
\text { et al., } \\
2010 \text { [28] }\end{array}$ & $\begin{array}{l}\text { Cross- } \\
\text { sectional }\end{array}$ & $\begin{array}{l}3090 \text { idiopathic PD } \\
\text { patients }\end{array}$ & $\begin{array}{l}\text { Not stated (recruited } \\
\text { from movement dis- } \\
\text { order centres in } \\
\text { Canada and America) }\end{array}$ & $\begin{aligned} \text { - } & \text { Massachusetts } \\
& \text { Gambling } \\
& \text { Screen } \\
\text { - } & \text { MIDI } \\
\text { - } & \text { DSM-IV-TR }\end{aligned}$ & $\begin{array}{l}\text { - Significantly higher frequency of } \\
\text { ICDs found in DA-treated PD pa- } \\
\text { tients } \\
\text { - 2.6-fold risk of ICD development } \\
\text { in patients treated with DA than } \\
\text { with levodopa } \\
\text { - Combination treatment with lev- } \\
\text { odopa and DA provides greater } \\
\text { risk of development of ICDs than } \\
\text { DA alone }\end{array}$ \\
\hline
\end{tabular}

CGT Cambridge gambling task; DA dopamine agonist; DSM-IV-TR Diagnostic and Statistical Manual of Mental Disorders, 4th edition, text revision; EDT experimental discounting task; ICDs impulse control disorders; LED total daily levodopa daily equivalent dose; MIDI Minnesota Impulsive Disorders Interview; PD Parkinson disease; PG pathological gambling; RLS restless legs syndrome.

taking DA [33]. Involvement of the insular cortex has been implied after imaging has shown an increased activation in patients with PD who demonstrate impulsive behaviours [31]. VBM has demonstrated anatomical change with a loss of volume of both the amygdala and OFC found in patients with ICDs compared to healthy controls [32].

\subsection{Genetic influence on development of impulsive behaviour (Table 3)}

Polymorphism of the D3 dopamine receptor is independently associated with the development of impul- sive behaviours in patients with PD. No such association has been found for other variants of dopamine receptors [35]. Eisenegger et al. [36] has also demonstrated a further possible genetic component that may influence the development of compulsive behaviours in patients with PD: administration of L-DOPA was found to result in significantly greater gambling tendencies in healthy males with the dopamine receptor $4 / 7$ polymorphism genotype compared to the 4/4 polymorphism.

\subsection{Surgical studies (Table 4)}

Subthalamic nucleus (STN) involvement in the development of ICDs in patients with PD has been sug- 
Table 2

Imaging studies of impulse control disorders in Parkinson disease

\begin{tabular}{|c|c|c|c|c|c|}
\hline Study & Design & Participants & Inclusion criteria & Methodology & Findings \\
\hline $\begin{array}{l}\text { Hollander } \\
\text { et al., } \\
2008 \text { [29] }\end{array}$ & $\begin{array}{l}\text { RCT } \\
\text { (double- } \\
\text { blind) }\end{array}$ & $\begin{array}{l}53 \\
\text { (21 PD PG patients } \\
\text { [lithium or placebo], } \\
32 \text { age and sex- } \\
\text { matched controls) }\end{array}$ & $\begin{array}{l}\text { Structured clinical } \\
\text { interview for } \\
\text { DSM-IV with } \\
\text { diagnosis of PG }\end{array}$ & FDG-PET scan & $\begin{array}{l}\text { - rGMR within orbitofrontal lobe of pre- } \\
\text { frontal cortex greater in PD PG patients } \\
\text { than in controls } \\
\text { - PG patients demonstrated reduced grey } \\
\text { matter activity compared to controls at } \\
\text { baseline }\end{array}$ \\
\hline $\begin{array}{l}\text { Keitz } \\
\text { et al., } \\
2008 \text { [30] }\end{array}$ & Case-control & $\begin{array}{l}23 \\
\text { (11 PD patients and } \\
12 \text { healthy controls) }\end{array}$ & $\begin{array}{l}\text { UK Parkinson's } \\
\text { Disease Society } \\
\text { Brain Bank } \\
\text { criteria }\end{array}$ & $\begin{array}{l}\text { fMRI with mone- } \\
\text { tary feedback }\end{array}$ & $\begin{array}{l}\text { - Significantly increased activity in medial } \\
\text { prefrontal cortex with monetary feedback } \\
\text { in PD patients vs. controls }\end{array}$ \\
\hline $\begin{array}{l}\text { Cilia } \\
\text { et al., } \\
2008 \text { [31] }\end{array}$ & Case-control & $\begin{array}{l}80 \\
(11 \text { PD patients with } \\
\text { PG, } 40 \text { matched PD } \\
\text { controls, } 29 \text { age- } \\
\text { matched healthy } \\
\text { controls) }\end{array}$ & DSM-IV-TR (PG) & SPECT & $\begin{array}{l}\text { - PD patients with PG vs. PD controls } \\
\text { * Increased clusters of perfusion in right } \\
\text { lateral OFC extending into insula and } \\
\text { globus pallidus with extension into nu- } \\
\text { cleus accumbens } \\
\text { * Greater rCBF in right hipp- } \\
\text { ocampus, parahippocampal } \\
\text { gyrus and amygdala } \\
\text { - PD patients with PG vs. healthy controls } \\
\text { * Increased activity in insular } \\
\text { cortex, lateral OFC with invol- } \\
\text { vement of putamen and caudate nucleus }\end{array}$ \\
\hline $\begin{array}{l}\text { Ibarretxe- } \\
\text { Bilbao } \\
\text { et al., } \\
2009 \text { [32] }\end{array}$ & Case-control & $\begin{array}{l}48 \\
(24 \mathrm{PD} \text { and } 24 \text { age, } \\
\text { gender and education- } \\
\text { matched controls) }\end{array}$ & $\begin{array}{l}\text { UK Parkinson's } \\
\text { Disease Society } \\
\text { Brain Bank criteria }\end{array}$ & IGT; VBM & $\begin{array}{l}\text { - PD patients had an increased tendency to } \\
\text { select less advantageous decks in the IGT } \\
\text { than controls } \\
\text { - VBM demonstrated significant loss of vol- } \\
\text { ume in right amygdala and bilaterally in } \\
\text { orbitofrontal cortex }\end{array}$ \\
\hline $\begin{array}{l}\text { Voon } \\
\text { et al., } \\
\text { 2010b [33] }\end{array}$ & Case-control & $\begin{array}{l}44 \\
\text { (14 PD patients with } \\
\text { ICDs, } 14 \text { PD control } \\
\text { patients and } 16 \\
\text { healthy controls) }\end{array}$ & $\begin{array}{l}\text { Queen Square } \\
\text { Brain Bank } \\
\text { criteria; DSM- } \\
\text { IV-TR and } \\
\text { McElroy's } \\
\text { criteria } \\
\text { (ICDs) }\end{array}$ & $\begin{array}{l}\text { Probabilistic } \\
\text { learning task; } \\
\text { fMRI }\end{array}$ & $\begin{array}{l}\text { - PD patients with ICDs - enhan- } \\
\text { ced learning from gain outcomes } \\
\text { (also associated with increased } \\
\text { ventral striatal activity); greater } \\
\text { OFC activity vs. PD controls in response } \\
\text { to gain and loss } \\
\text { - PD controls taking DA demonstrated slow- } \\
\text { er learning to negative outcomes and } \\
\text { demonstrated increased activity in the an- } \\
\text { terior insular and right orbitofrontal cor- } \\
\text { tices }\end{array}$ \\
\hline $\begin{array}{l}\text { O'Sullivan } \\
\text { et al., } \\
2011[34]\end{array}$ & Case-control & $\begin{array}{l}18 \\
\text { L-DOPA treated PD } \\
\text { patients ( } 11 \text { with } \\
\text { ICDs, } 7 \text { without })\end{array}$ & $\begin{array}{l}\text { Queen Square } \\
\text { Brain Bank for } \\
\text { Neurological } \\
\text { Disorders }\end{array}$ & $\begin{array}{l}{ }^{11} \mathrm{C} \text {-raclopride } \\
\text { PET scan; } \\
\text { reward-related } \\
\text { cues }\end{array}$ & $\begin{array}{l}\text { - Exposure to reward-related cues demon- } \\
\text { strated positive correlation between sensa- } \\
\text { tion seeking and }{ }^{11} \mathrm{C}-\text {-raclopride binding } \\
\text { potential in putamen and caudate nuclei in } \\
\text { PD patients with ICDs } \\
\text { - }{ }^{11} \text { C-raclopride binding potential in ven- } \\
\text { tral striatum significantly reduced in PD } \\
\text { patients with ICDs vs. PD controls post- } \\
\text { reward cue exposure }\end{array}$ \\
\hline
\end{tabular}

DA dopamine agonist; DSM-IV-TR Diagnostic and Statistical Manual of Mental Disorders, 4th edition, text revision; FDG-PET 18Ffluorodeoxyglucose positron emission tomography; fMRI functional magnetic resonance imaging; ICDs impulse control disorders; IGT Iowa gambling task; L-DOPA levodopa; OFC orbitofrontal cortex; PD Parkinson disease; PG pathological gambling; rCBF regional cerebral blood flow; RCT randomised controlled trial; rGMR relative glucose metabolic rates; SPECT single photon emission computed tomography; VBM voxel-based morphometry. 
Table 3

Genetic influence on the development of impulse control disorders in Parkinson disease

\begin{tabular}{|c|c|c|c|c|c|}
\hline Study & Design & Participants & Inclusion criteria & Methodology & Findings \\
\hline $\begin{array}{l}\text { Lee et al., } \\
2009 \text { [35] }\end{array}$ & $\begin{array}{l}\text { Cross- } \\
\text { sectional }\end{array}$ & $\begin{array}{l}963 \\
\text { (404 PD patients, } 559 \\
\text { healthy controls) }\end{array}$ & $\begin{array}{l}\text { UK Parkinson's } \\
\text { Disease Society } \\
\text { Brain Bank } \\
\text { diagnostic } \\
\text { criteria; MIDI }\end{array}$ & $\begin{array}{l}\text { - Genotyping for } \\
\text { allelic variants } \\
\text { of dopamine } \\
\text { and glutamate } \\
\text { receptors; } \\
\text { serotonin } \\
\text { transporter } \\
\text { genes }\end{array}$ & $\begin{array}{l}\text { - DRD3 p.S9G polymorphism in- } \\
\text { dependently associated with im- } \\
\text { pulsive behaviour in PD patient } \\
\text { group } \\
\text { - No association found with } \\
\text { DRD2Taq1A polymorphism }\end{array}$ \\
\hline $\begin{array}{l}\text { Eisenegger } \\
\text { et al., } \\
2010 \text { [36] }\end{array}$ & $\begin{array}{l}\text { RCT } \\
\text { (double- } \\
\text { blind, } \\
\text { placebo } \\
\text { controlled) }\end{array}$ & 200 males & $\begin{array}{l}\text { Exclusion of signific- } \\
\text { ant medical disorders } \\
\text { (particularly psychi- } \\
\text { atric and neurological) }\end{array}$ & $\begin{array}{l}\text { - L-DOPA vs. } \\
\text { placebo } \\
\text { administration } \\
\text { followed by } \\
\text { gambling task }\end{array}$ & $\begin{array}{l}\text { - Subjects with dopamine receptor } \\
4 / 7 \text { polymorphism had increased } \\
\text { gambling tendency vs. } 4 / 4 \text { poly- } \\
\text { morphism }\end{array}$ \\
\hline
\end{tabular}

MIDI Minnesota Impulsive Disorders Interview; PD Parkinson disease; RCT randomised controlled trial.

Table 4

Deep brain stimulation and impulse control disorders in Parkinson disease

\begin{tabular}{|c|c|c|c|c|c|}
\hline Study & Design & Participants & Inclusion criteria & Methodology & Findings \\
\hline $\begin{array}{l}\text { Hälbig et al., } \\
2009 \text { [37] }\end{array}$ & $\begin{array}{l}\text { Cross- } \\
\text { sectional }\end{array}$ & $\begin{array}{l}53(16 \mathrm{PD}+\mathrm{DBS} \\
\text { patients and } 37 \mathrm{PD} \\
\text { controls })\end{array}$ & $\begin{array}{l}\text { UK Parkinson's } \\
\text { Disease Society } \\
\text { Brain Bank } \\
\text { diagnostic } \\
\text { criteria }\end{array}$ & BIS & $\begin{array}{l}\text { - BIS scores significantly higher in } \\
\text { PD patients receiving DBS treat- } \\
\text { ment vs. those without }\end{array}$ \\
\hline $\begin{array}{l}\text { Rodriguez- } \\
\text { Oroz et al., } \\
2011[38]\end{array}$ & Case-control & $\begin{array}{l}28 \text { patients with surgi- } \\
\text { cally implanted STN } \\
\text { (10 PD patients with } \\
\text { ICDs, } 9 \text { patients with } \\
\text { L-DOPA-associated } \\
\text { dyskinesia, } 9 \text { PD } \\
\text { controls) }\end{array}$ & $\begin{array}{l}\text { UK Parkinson's } \\
\text { Disease Society } \\
\text { Brain Bank } \\
\text { diagnostic } \\
\text { criteria }\end{array}$ & $\begin{array}{l}\text { EEG recordings } \\
\text { in 'on' and 'off' } \\
\text { motor states }\end{array}$ & $\begin{array}{l}\text { - Specific oscillatory activity in } \\
\text { theta-alpha band identified in } \\
\text { subthalamic nucleus region in PD } \\
\text { patients with ICDs } \\
\text { - L-DOPA induces theta-alpha } \\
\text { band oscillatory activity in the } \\
\text { ventral subthalamic nucleus in } \\
\text { PD patients with ICDs }\end{array}$ \\
\hline $\begin{array}{l}\text { Oyama et al., } \\
2011 \text { [39] }\end{array}$ & Clinical trial & $\begin{array}{l}32 \text { (16 PD patients } \\
\text { for STN-DBS and } 16 \\
\text { age-matched PD con- } \\
\text { trols on dopaminergic } \\
\text { medication) }\end{array}$ & $\begin{array}{l}\text { UK Parkinson's } \\
\text { Disease Society } \\
\text { Brain Bank } \\
\text { diagnostic } \\
\text { criteria }\end{array}$ & $\begin{array}{l}\text { IGT (pre-op and } \\
2-4 \text { weeks post- } \\
\text { op) }\end{array}$ & $\begin{array}{l}\text { - IGT demonstrated increased im- } \\
\text { pulsivity in patients on STN-DBS } \\
\text { vs. PD controls } \\
\text { - Poorer performance in IGT by } \\
\text { STN-DBS patients during 'on' } \\
\text { session than 'off' }\end{array}$ \\
\hline
\end{tabular}

BIS Barratt impulsiveness scale; DBS deep brain stimulation; EEG electroencephalography; ICDs impulse control disorders; IGT Iowa gambling task; L-DOPA levodopa; PD Parkinson disease; STN-DBS subthalamic nucleus - deep brain stimulation.

gested by several recent studies [37-39]. These studies demonstrate that patients receiving subthalamic nucleus deep brain stimulation (STN-DBS) show a higher prevalence of impulsive behaviours than controls [37, 39]. STN involvement is also proposed given that LDOPA induces significant oscillatory activity in this region in affected patients [38].

\section{Discussion}

Of the 16 original studies which have been reviewed to appraise the current evidence on the pathophysiology of ICDs in PD $31.2 \%$ focussed on the medications used in the management of PD, $37.5 \%$ on imaging studies undertaken at baseline and during tasks to induce impulsive activity, $12.5 \%$ on genetic predisposition and $18.8 \%$ on the outcome of STN-DBS.

DAs can be seen as one of the main culprits in the induction of impulsive behaviour in DA-medicated patients, with potential to increase the likelihood of ICD development by 3 times [28]. The potential to induce compulsive behaviour in patients with PD whilst improving motor symptoms may be due to underlying involvement of dopamine receptor subtypes. Pramipexole, one of the most commonly used DAs, has been shown to be relatively selective to dopamine D3 receptors as opposed to D1 and D2 receptors [11]. Evidence 
suggests uneven distribution of these dopamine receptor subtypes within different brain regions: D1 and D2 receptors are found to be abundant in the dorsal striatum whilst D3 receptors are found in abundance in the ventral striatum [12]. Whilst action of dopamine within the dorsal striatum may improve motor symptoms [12], activation of D3 receptors of the ventral striatum may induce impulsive behaviour $[13,14]$.

The involvement of dopamine receptors has also been suggested by genetic studies such as that of Eisenegger et al. [36], who demonstrated a genetic predisposition to pathological gambling in individuals with a particular polymorphism of the dopamine D4 receptor. Dopamine D4 receptors are located within the mesocorticolimbic pathway, particularly within the nucleus accumbens [15]. It may be that the $4 / 7$ polymorphism of the dopamine D4 receptor is more susceptible to dopamine-mediated activation than the $4 / 4$ polymorphism, leading to overactivity of the mesocorticolimbic pathway and, therefore, an increased tendency towards impulsive behaviours. Dopamine D3 receptors, predominantly distributed within the limbic system $[6,16]$ regulate dopamine release within the mesocorticolimbic pathway [17]. The association of the DRD3 p.S9G polymorphism in the development of ICDs in PD may be explained by this form of the receptor demonstrating a reduced binding affinity to dopamine [35], which may result in inappropriate dopamine-mediated stimulation of the mesocorticolimbic pathway.

Imaging studies have revealed overactivity of the mesocorticolimbic pathway, which consists of the OFC, amygdala, hippocampus and insula [29-34]. The OFC, together with the amygdala, demonstrate a role in learning from negative events [18]. Impulsive behaviours in PD may, therefore, be explained by dysfunction in the OFC-amygdala circuit resulting in an inability to learn from negative outcomes due to OFC overactivity. Overactivity of the hippocampus, which is associated with novelty processing [18], and the insular cortex, which is important in decision making [18], along with the OFC and amygdala may provide a pathological basis for the development of ICDs in PD. Involvement of the STN may add to this pathological basis, as shown by the presence of impulsive behaviour after STN-DBS in patients with PD [37-39]. This may be explained by possible indirect activation of the OFC via the hyper-direct pathway $[19,20]$ or disinhibition induced by DBS [21,22].

\subsection{Limitations}

This review has methodological limitations. Unpublished studies have not been included, thereby limiting acknowledgment of the most up-to-date evidence. This review is also restricted by limitations of the studies themselves. Recruitment of patients in all studies occurred within a clinical setting, predominantly at specialised clinics, therefore providing a biased insight into impulsive behaviours in patients with PD. ICDs can resemble obsessive-compulsive disorders, making it difficult to distinguish ICDs as a homogenous group [23]. It is also important to consider interviewer and responder bias in cases where questionnaires have been used given the stigma surrounding the topic of impulsive behaviours. In the case of imaging studies, the activity of certain brain regions does not necessarily signify a direct association of this area with a particular process e.g. gambling. Evidence derived from STN-DBS needs to take into account the possibility of lesioning effects of the STN, altered task performance from reduced motivation and the influence of pre- and post-operative management with DAs.

\subsection{Clinical implications}

Patients and their carers should be informed of the possibility of developing ICDs given its negative influences on quality of life. Patients may be screened using the validated Questionnaire for Impulsive-Compulsive Disorders in PD (QUIP) [2]. Patients and carers need to be educated and warned of the development of pathological gambling, hypersexuality and other such impulsive behaviours. Clinicians should assess the likelihood of a patient developing ICDs by using QUIP and should prompt the discussion of such behaviour with appropriate adjustment of medication accordingly, involving carers where possible. Surgical intervention needs to be carefully considered given the limited evidence.

\subsection{Future research}

Research is required to further investigate the role of medication used in the management of PD, particularly DAs, in the development of ICDs. Randomised controlled trials are required to provide a better hierarchy of evidence and a greater number of prospective studies are required in order to better establish potential causative factors. Given the limited evidence of the effects of STN-DBS, further research is required in this area. It may also be important to distinguish the different behaviours in ICDs e.g. compulsive shopping, pathological gambling and hypersexuality and determine their pathophysiology in PD in order to find better identify potential treatment methods. 


\section{Conclusion}

Our systematic review of the recent research on the pathophysiology of ICDs in PD suggests that both intrinsic and extrinsic factors can be involved in the development of ICDs in patients with PD. Genetic polymorphisms together with dysfunction of the mesocorticolimbic pathway and STN may contribute to the development of impulsive behaviours in a predisposed individual. ICDs may also be induced by medications used in the management of PD, particularly DAs. Further evidence is required to determine the exact pathophysiology of ICDs in PD in order to inform the clinical management of these debilitating behaviours in the context of a neurodegenerative condition which affects patients' health-related quality of life in multiple ways.

\section{References}

[1] National Institute for Health and Clinical Excellence. Parkinson's Disease. [CG35]. London: National Institute for Health and Clinical Excellence, 2006.

[2] V. Voon, A.R. Mehta and M. Hallett, Impulse control disorders in Parkinson's disease: recent advances, Curr Opin Neurol 24(4) (2011), 324-330.

[3] D. Weintraub, Dopamine and impulse control disorders in Parkinson's disease, Ann Neurol 64(S2) (2008), S93-S100.

[4] K. Wu, M. Politis and P. Piccini, Parkinson disease and impulse control disorders: a review of clinical features, pathophysiology and management, Postgrad Med J 85 (2009), 590596.

[5] C.R. Bjarkam and J.C. Sørensen, Therapeutic strategies for neurodegenerative disorders: emerging clues from Parkinson's disease, Biol Psychiatry 56(4) (2004), 213-216.

[6] P. Sokoloff, B. Giros, M.P. Martres, M.L. Bouthenet and J.C. Schwartz, Molecular cloning and characterization of a novel dopamine receptor (D3) as a target for neuroleptics, Nature 347(6289) (1990), 146-151.

[7] S. Rahman, H.J. Griffin, N.P. Quinn and M. Jahanshahi, Quality of life in Parkinson's disease: the relative importance of the symptoms, Mov Disord 23(10) (2008), 1428-1434.

[8] M.A. Hely, J.G.L. Morris, W.G.J. Reid and R. Trafficante, Sydney multicenter study of Parkinson's disease: non L-doparesponsive problems dominate at 15 years, Mov Disord 20(2) (2005), 190-199.

[9] K.R. Chaudhuri, D.G. Healy and A.H. Schapira, National Institute for Clinical Excellence. Non-motor symptoms of Parkinson's disease: diagnosis and management, Lancet Neurol 5(3) (2006), 235-245.

[10] C.G. Goetz, W. Poewe, O. Rascol and C. Sampaio, Evidencebased medical review update: pharmacological and surgical treatments of Parkinson's disease: 2001 to 2004, Mov Disord 20(5) (2005), 523-539.

[11] M. Gerlach, K. Double, T. Arzberger, F. Leblhuber, T. Tatschner and P. Riederer, Dopamine receptor agonists in current clinical use: comparative dopamine receptor binding profiles defined in the human striatum, J Neural Transm 110(10) (2003), 1119-1127.
[12] E.V. Gurevich and J.N. Joyce, Distribution of dopamine D3 receptor expressing neurons in the human forebrain: comparison with D2 receptor expressing neurons, Neuropsychopharmacol 20(1) (1999), 60-80.

[13] C. Holden, 'Behavioural' addictions: do they exist? Science 294(5544) (2001), 980-982.

[14] V. Le Foll, S.R. Goldberg and P. Sokoloff, The dopamine D3 receptor and drug dependence: effects on reward or beyond? Neuropharmacol 49(4) (2005), 525-541.

[15] A.M. Murray, T.M. Hyde, M.B. Knable, M.M. Herman, L.B. Bigelow, J.M. Carter et al., Distribution of putative D4 dopamine receptors in postmortem striatum from patients with schizophrenia, J Neurosci 15(3) (1995), 2186-2191.

[16] M.L. Bouthenet, E. Souil, M.P. Martres, P. Sokoloff, B. Giros and J.C. Schwartz, Localization of dopamine D3 receptor mRNA in the rat brain using in situ hybridization histochemistry: comparison with dopamine D2 receptor mRNA, Brain Res 564(2) (1991), 203-219.

[17] P.C. Chen, C.L. Lao and J.C. Chen, The D(3) dopamine receptor inhibits dopamine release in $\mathrm{PC}-12 / \mathrm{hD} 3$ cells by autoreceptor signaling via PP-2B, CK1, and Cdk-5, J Neurochem 110(4) (2009), 1180-1190.

[18] E. Camara, A. Rodriguez-Fornells and T.F. Münte, Functional connectivity of reward processing in the brain, Front Hum Neurosci 2 (2008), 19.

[19] M. Ernst, K. Bolla, M. Mouratidis, C. Contoreggi, J.A. Matochik, V. Kurian et al., Decision-making in a risk-taking task: a PET study, Neuropsychopharmacol 26(5) (2002), 682-691.

[20] G. Northoff, S. Grimm, H. Boeker, C. Schmidt, F. Bermophl, A. Heinzel et al., Affective judgement and beneficial decision making: ventromedial prefrontal activity correlates with performance in the Iowa Gambling Task, Hum Brain Mapp 27(7) (2006), 572-587.

[21] D. Raucher-Chéné, C.L. Charrel, A.D. de Maindreville and F. Limosin, Manic episode with psychotic symptoms in a patient with Parkinson's disease treated by subthalamic nucleus stimulation: improvement on switching the target, J Neurol Sci 273(1-2) (2008), 116-117.

[22] P. Doshi and P. Bhargava, Hypersexuality following subthalamic nucleus stimulation for Parkinson's disease, Neurol India 56(4) (2008), 476-486.

[23] A. Kummer and A.L. Teixeira, Neuropsychiatry of Parkinson's disease, Arq Neuropsiquiatr 67(3B) (2009), 930-939.

[24] W.G. Ondo and D. Lai, Predictors of impulsivity and reward seeking behavior with dopamine agonists, Parkinsonism Relat Disord 14(1) (2008), 28-32.

[25] A. Imamura, Y.E. Geda, J. Slowinski, Z.K. Wszolek, L.A. Brown and R.J. Uitti, Medications used to treat Parkinson's disease and the risk of gambling, Eur J Neurol 15(4) (2008), 350-354.

[26] D.M. Torta, L. Castelli, M. Zibetti, L. Lopiano and G. Geminiani, On the role of dopamine replacement therapy in decisionmaking, working memory, and reward in Parkinson's disease: does the therapy-dose matter? Brain Cogn 71(2) (2009), 8491.

[27] V. Voon, B. Reynolds, C. Brezing, C. Gallea, M. Skaljic, V. Ekanayake et al., Impulsive choice and response in dopamine agonist-related impulse control behaviors, Psychopharmacol 207(4) (2010), 645-659.

[28] D. Weintraub, J. Koester, M.N. Potenza, A.D. Siderowf, M. Stacy, V. Voon et al., Impulse control disorders in Parkinson disease: a cross-sectional study of 3090 patients, Arch Neurol 67(5) (2010), 589-595. 
[29] E. Hollander, M.S. Buchsbaum, M.M. Haznedar, J. Berenguer, H.A. Berlin, W. Chaplin et al., FDG-PET study in pathological gamblers. 1. Lithium increases orbitofrontal, dorsolateral and cingulated metabolism, Neuropsychobiol 58(1) (2008), 37-47.

[30] M. Keitz, J. Koerts, R. Kortekaas, R. Kenken, B.M. de Jong and K.L. Leenders, Prefrontal cortex and striatal activation by feedback in Parkinson's disease, Brain Res 1236 (2008), 225-233.

[31] R. Cilia, C. Siri, G. Marotta, I.U. Isaias, D. De Gaspari, M. Canesi et al., Functional abnormalities underlying pathological gambling in Parkinson disease, Arch Neurol 65(12) (2008), 1604-1611.

[32] N. Ibarretxe-Bilbao, C. Junque, E. Tolosa, M.J. Marti, F. Valldeoriola, N. Bargallo et al., Neuroanatomical correlates of impaired decision-making and facial emotion recognition in early Parkinson's disease, Eur J Neurosci 30(6) (2009), 1162-1171.

[33] V. Voon, M. Pessiglione, C. Brezing, C. Gallea, H.H. Fernandez, R.J. Dolan et al., Mechanisms underlying dopaminemediated reward bias in compulsive behaviors, Neuron $\mathbf{6 5}(1)$ (2010), 135-142.

[34] S.S. O'Sullivan, K. Wu, M. Politis, A.D. Lawrence, A.H. Evans, S.K. Bose et al., Cue-induced striatal dopamine re- lease in Parkinson's disease-associated impulsive-compulsive behaviours, Brain 134(4) (2011), 969-978.

[35] J.Y. Lee, E.K. Lee, S.S. Park, J.Y. Lim, H.J. Kim, J.S. Kim et al., Association of DRD3 and GRIN2B with impulse control and related behaviours in Parkinson's disease, Mov Disord 24(12) (2009), 1803-1810.

[36] C. Eisenegger, D. Knoch, R.P. Ebstein, L.R. Gianotti, P.S. Sándor and E. Fehr, Dopamine receptor D4 polymorphism predicts the effect of L-DOPA on gambling behavior, Biol Psychiatry 67(8) (2010), 702-706.

[37] T.D. Hälbig, W. Tse, P.G. Frisina, B.R Baker, E. Hollander, H. Shapiro et al., Subthalamic deep brain stimulation and impulse control in Parkinson's disease, Eur J Neurol 16(4) (2009), 493-497.

[38] M.C. Rodriguez-Oroz, J. López-Azcárate, D. Garcia-Garcia, M. Alegre, J. Toledo, M. Valencia et al., Involvement of the subthalamic nucleus in impulse control disorders associated with Parkinson's disease, Brain 134(1) (2011), 36-49.

[39] G. Oyama, Y. Shimo, S. Natori, M. Nakajima, H. Ishii, H. Arai et al., Acute effects of bilateral subthalamic stimulation on decision-making in Parkinson's disease, Parkinsonism Relat Disord 17(3) (2011), 189-193. 


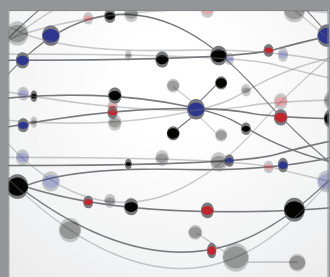

The Scientific World Journal
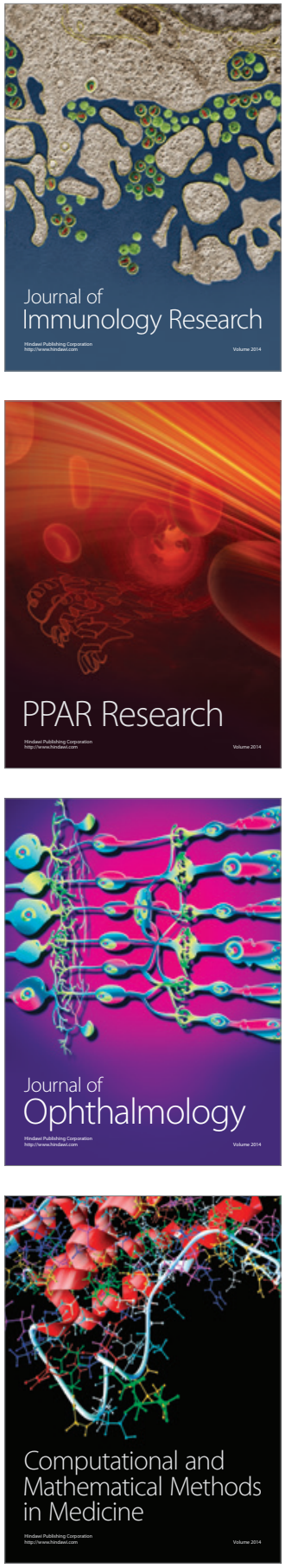

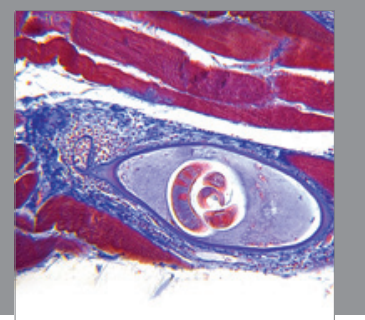

Gastroenterology

Research and Practice
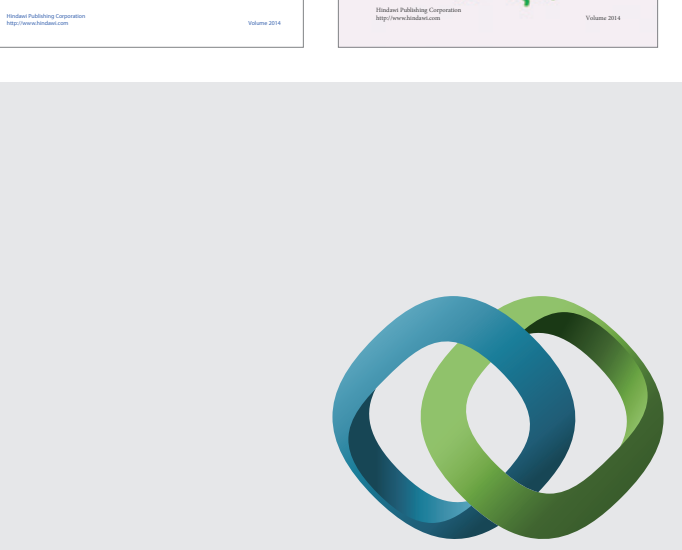

\section{Hindawi}

Submit your manuscripts at

http://www.hindawi.com
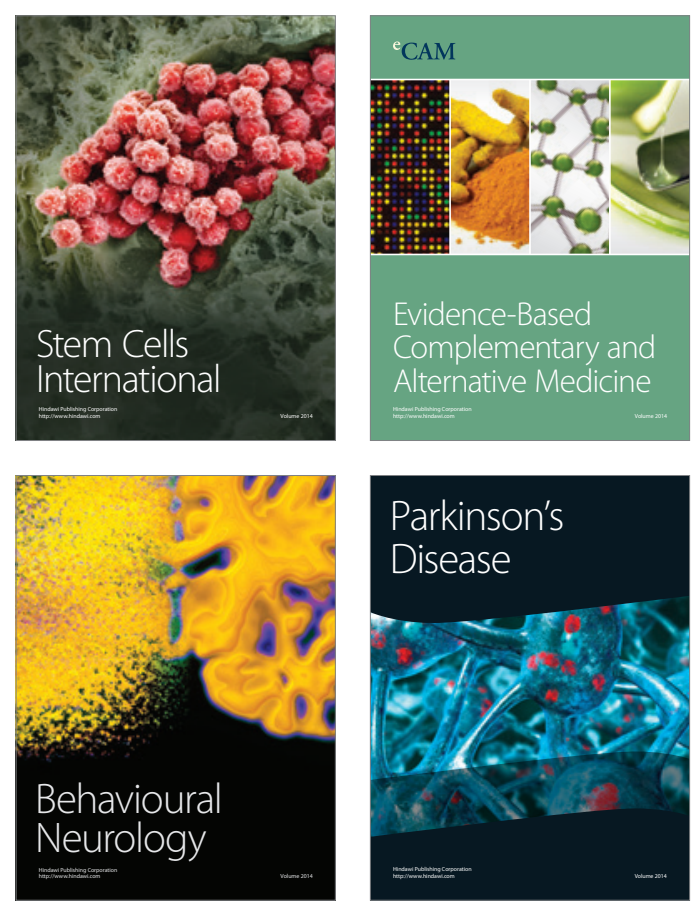

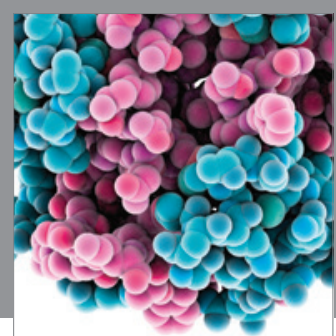

Journal of
Diabetes Research

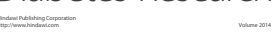

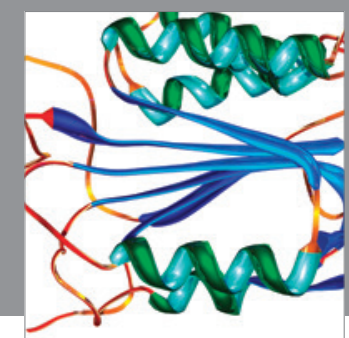

Disease Markers
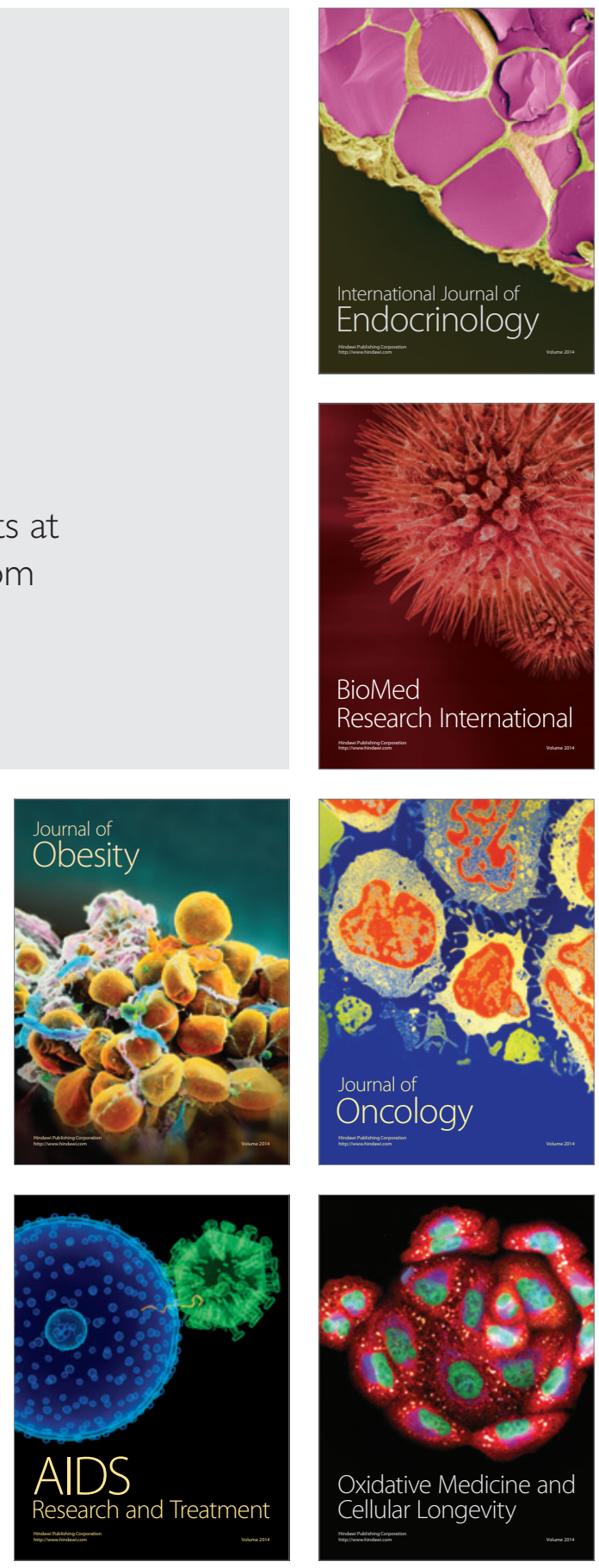